\title{
THE TRANSFUSION OF POLITICAL IDEAS AND INSTITUTIONS IN IOWA.
}

BY F. I. HERRIOTT.

The world has never seen more varied and extensive experiments in social and political institutions and methods of government than have taken place, or are now in progress, within the confines of the United States. The immense extent and variable topography of the country, the great diversity of soil and climate present original and persistent conditions that always exert powerful influences in moulding political institutions and the political character of a people. There has been a steady influx of various peoples, the numerous streams at times swelling into veritable floods, bringing with them all manner of customs, institutions and habits of thought and conduct, and all these in turn being modified more or less by succeeding waves of immigration. There has been a remarkable growth of local, state and national jurisdictions, starting from numerous isolated colonial local groups with more or less impotent central authorities that after years of friction and conflicts and ultimately through the pressure of necessity in a common struggle for national independence took on the political form of co-ordinate sovereign states yet all at once subject to a masterful national power, constituting a complex of governments, the like of which has never been seen before. The transplanting of institutions from the old world to the new, from the older eastern states to the middle west and to the far west, with the accompanying transfusion of political ideas, with the action and reaction of these upon local institutions and indigenous customs, as the currents of population have made their way across the continent, now coalescing here and there, presents a vast panorama of human development that is bewildering but withal magnificent and fascinating to him who will but pause to observe and study. 
By her geographical location Iowa has been at the crossroads, so to speak, of the continent. Into her gates and through her borders have poured innumerable and unending streams of people, foreign born, as well as native Americans, bringing with them the political inheritances of their parent states. Between $1836^{\circ}$ and 1860 the population increased by leaps and bounds, from 10,531 in the former to 673,779 in the latter year. The earliest settlers chiefly came from southern Obio, Indiana, Illinois and the more northerly of the southern states. The bulk of these first immigrants came from the southern states or were remotely of southern extraction, and they settled mostly in the southeastern and southern portions of the State. Later, large contingents came from New England, Pennsylvania and New York, these settling largely in the central and northern parts of the State. The disturbances in Europe in 1848 and the following year caused great swarms to come from Germany and Ireland to mingle with our population. In later years thousands of Scandinavians came among us.

During the nearly three-quarters of a century that social and political institutions in Iowa have been undergoing the processes of transplanting, creation, modification and growth, what has been the effect of the commingling of these various streams of population? In the struggles for political supremacy of the different elements what political ideas and institutions became predominant? To what extent was the outcome in legislation an overthrow of one idea, of one institution, by another of different type? To what extent was there coalescence? To what shiftings of population shall we ascribe the changes made in county government from the system of control by commissioners in 1838 to the autocratic county judge system in 1851, then the abandonment of that in 1860 and the adoption of the present supervisoral system? Why was it that receiving the body of our territorial laws from Michigan where the New England township system of government, namely, direct local control by town or mass meeting, was 
in vogue, we rejected that mode and adopted the trustee system so much less democratic? Our sister state of Illinois exhibits a most interesting struggle for supremacy between two political systems, the township meeting plan and the county government scheme, the former encroaching steadily upon the latter until the area of the county government control is now small and confined to the southern part of that.state. To what are we to ascribe the absence of such a struggle in Iowa? Are our people less vigorously democratic, less assertive of their right to control their local affairs?

New social and political elements have been injected into our state life with the great influx of Europeans. Many of them came to us because oppressive laws and harsh conditions drove them from their fatherlands. Did they bring with them their old resentment against the established order to such an extent as to affect vitally the drift of our politics and legislation? Have socialistic doctrines and tendencies increased among us by reason of these numerous old world elements? May we perceive and trace these influences in the budgets of our cities and of our State government, and in the attitude of our citizens towards the regulation and control of corporate business undertakings and monopolistic enterprises? In what various ways have these foreign born citizens engrafted their old world social and religious customs upon local traditions and customs in the communities where they predominate? What effect have these had upon the development of local institutions and the course of local political life? In the long drawn out struggle over the control of the liquor traffic in this State, what parts have the Puritan and the Bourbon and the foreign elements played? Each has exerted constant and powerful influences and effected mightily the results.

Readers of Plato, Sir Thomas More, or Rousseau, very naturally conclude that the making of laws and the establishment of institutions of government are merely an exercise of mind, or a matter simply of election. From their 
writings one infers that out of the depths of their inner consciousness men spin the fabric of law and of political organization, and when needed they can be created de novo out of hand. Rarely does anything like this, even in appearance, ever take place. Governments, like everything else, have arisen to meet the needs of men in the struggle for existence. Conditions necessitate or suggest methods of action and time produces habits of conduct, and these eventually crystallize into customs and laws and institutions.

When people emigrate to a new and uninhabited country they take with them a stock of old ideas and habits of thought and action which they follow and utilize, as a matter of course, in their new homes. If the conditions on the frontier or in their new homes are not wholly adverse they naturally seek to establish the social and political systems under which they were reared. They reproduce familiar and customary institutions. If the institutions first established fail to work satisfactorily, those social groups having different: political inheritances that were at first in the minority, or that come later and mingle with the original population, will agitate for the adoption of the institutions of their parent states.

With the process of time, experience induces modifications and increase of forms and procedure, but it is all a refashioning of the familiar and long-tried institutions or rules. of action. There is little severance from the past in the creations of the present. The experience of other communities or states may be utilized and we may consciously import ideas and institutions; but the importations or innovations. are not abnormal nor contradictory to our political thought and organization; else they could not be engrafted in our. system of laws and government-public opinion would not tolerate them. In these later years legislation in our states. has become more and more a composite of the laws of many states. Laws that work well in one commonwealth are incorporated bodily into our own statute books; or some device is: VงE. VI-4. 
taken from one state, a different method affecting a related institution from another state; or out of a consideration of the laws and practice of other states our law makers receive suggestions that lead to the formation of a new scheme of administration. These various processes of transfusion of political ideas and institutions are strikingly shown in the history of Iowa.

The influence of the traditions and institutions of ancestral states is clearly exhibited in the messages of the early governors, especially those of Governors Lucas and Grimes. Fresh from Ohio, where the formative influences in government were just then especially manifest, the recommendations of Iowa's first governor respecting schools and township government and the control of the liquor traffic were in large part but an echo of the political discussion of that state. Governor Grimes, although from a corner of the State where public sentiment was reactionary in its drift, represents the democracy and liberal traditions of Puritan New England. $\mathrm{He}$ brought from the bills of New Hampshire an advanced liberalism and his far-sighted policies with regard to education and the care of the insane and defective classes in society voiced the humanitarianism that in general characterized the political thought and institutions of the Puritan states, rather than of the southern states.

The numerical preponderance of people from the southern states, of those who, although coming from southern Ohio, Indiana, and Illinois, were originally emigrants from Kentucky, Tennessee, and the Virginias, or the immediate descendants of such emigrants, accounts in large part for the early predominance of county government and the trustee system of township control in the State. In this fact, too, we find the chief explanation of the yigorous opposition so long maintained against "forward" movements for state aid to education and the establishment and furtherance of state and local libraries and schools, and of state institutions for the care of the insane and unfortunate. The existence of 
virile southern traditions in our early state life was clearly exhibited in the great body of pro-slavery sentiment in the south half of Iowa just before and during the early days of the civil war, which manifested itself so often in acrimonious discussions and at times during the war in fierce animosities and belligerant outbreaks.

A very considerable proportion of the people of southern extraction that came into southern Iowa in such large numbers, prior to 1860 , trace their lineage back to that interesting sociological element in the history of all southern states that have their watersheds in the Appalachian mountainsnamely, the "poor whites!" This class arose from the thousands of "indentured white servants" that constituted the bulk of the manual laboring population of the first years of Maryland, Virginia, and the Carolinas. A large proportion were of the class known as "redemptioners," some were political prisoners, and a considerable number were "penal colonists," the output of the Old Bailey in London. With the social changes resulting upon the expansion of slavery the livlihood of this class became precarious with serious results to their welfare. They were landless and poor. The presence of slave labor made the labor of whites socially impossible because it was considered degrading. The outcome was that the poor whites became an idle, shiftless class, living in a promiscuous fashion among the plantations, or they moved back into the woods and mountains where they led a free existence hunting and trapping or farming. The most ambitious or restless moved west, settling in Kentucky and Tennessee, and when the same conditions began to pinch in those states, migrating thence to southern Ohio, Indiana and Illinois.

Among these southern folks were not a few Scotch-Irish, that sturdy stock that has played such a conspicuous part in the history of many American states. Prosperous in indus. try and in their religion in Ulster, in the north of Ireland, they were oppressed by discriminating laws and intolerant 
churchmen. After 1719 they came to America in immense swarms, settling first chiefly in western Pennsylvania, whence they spread south and west, following the valleys of the Blue Ridge, peopling the mountainous portions of the Virginias. and Carolinas, Kentucky and Tennessee. They constituted the dominant majority of the population in the regions they occupied, and with their stiff-backed notions of church and state, they exercised a profonnd influence upon the politics. and history. of those states. Many representatives of this vigorous race moved westward with the drift that brought such numbers of southerners into Iowa.

Besides these English and Scotch elements there were representatives of the German immigrants that came into. Pennsylvania and, like the Scotch, had made their way down the Appalachian ranges into the Virginias and Carolinas, whence they came west as the pioneers pushed the frontiers and gave them assurance of free homes and peaceful industry. There doubtless were, also, a few descendants. of the Huguenots that came into Virginia and South Carolina after the edict of Nantes. In addition to all these there was a noteworthy infusion of Quakers, or Friends, that traced their progenitors back to Maryland and North Carolina.

From the nature of their origin and social status the bulk of these southern elements that came into Iowa had extremely conservative views of the proper functions of government. They had been reared under the county governments of the southern states that were representative in character and that for the most part dealt with their citizens at long range. But little more than the "individualistic minimum" of government was deemed necessary, namely, provisions merely for the enforcement of the laws for the protection of life, liberty and property, and the maintenance of the courts and the execution of their orders and decrees. With people with such traditions that was the best government that involved the least government and a fortiori, the least expense. Popular education, care of the insane and defective classes, were not 
matters of urgent public necessity; they should be attended to by private individuals who were immediately concerned. In general this was the attitude of the southern elements in political discussions in Iowa in the ante bellum period. It is unquestionably in the existence of such inherited notions of the functions of government that we may discover the explanation of the repeated but vain recommendations of Iowa's second territorial governor, John Chambers, respecting the promotion of schools in the townships, and his mortification in 1843 at seeing "how little interest the important subject of education excites among us." Here and there, of course, many of their prominent representatives broke with their traditions and urged greater governmental activity in the establishment of eleemosynary institutions and in the furtherance of the public schools. The tenets of Presbyterianism were favorable to schools and education, and we find the members of this faith later joining with New Englanders in promoting secondary and higher schools.

Meantime while these streams were flowing into the State from the southlands, there were beginning to come small streams from the northlands that were to have an immediate and marked effect upon the general currents of social and political life in Iowa. The first to come were chiefly from New England. They then began to start from Now York and Pennsylvania, and then from northern Ohio and Indiana. Those from New England came mostly from the halls and precincts of Amherst, Andover, Bowdoin, Dartmouth, Harvard, and Yale. Many of them came as Home Missionaries to establish churches and schools, as "Father" Asa Turner and the celebrated "Iowa Band." They invaded the southeastern portions of the State, first founding an academy at Denmark, in Lee county, in 1843, and planning for a college that eventually materialized in Iowa College, at Davenport, but later removed to Grinnell; but they spread mostly through the central and northern counties. The later arrivals settled mostly in the latter portions of the State. It was 
mainly of these people that Professor L. F. Parker remarked that "Iowa pioneers had a passion for education." It was these New England folks chiefly, and their descendants from New York, Ohio and Indiana, that were the promoters of the fifty academies, colleges and universities that were incorporated in Iowa between 1838 and 1850 , and that gave Iowa the distinction of being the "Massachusetts of the west." Their incoming affected not only the course of the educational and religious history of the State, but it had the same pronounced effects upon the industrial and political history of the new commonwealth. These elements began to press for greater public expenditures for education, the discussion culminating in the work of Horace Mann and Amos Dean, in 1856. They began to agitate for the repeal of the constitutional restriction that prevented that establishment of banks. of note issue, which resulted in the repeal in. $18 \tilde{7} 7$ and the creation of the free banking system and the Iowa State Bank in 1858. It was these same elements that caused Iowa to take such a sturdy stand upon the subject of slavery, and that put James W. Grimes in the governor's chair. And later they overthrew the autocratic county judge system and substituted the supervisoral system, patterned more or less after the system in vogue in New York.

The history of these struggles for supremacy of the various political elements in the early career of Iowa, the transfusion of political ideas and institutions in local and state life, with the infusion of new elements and new ideas that came after 1860 with the incoming of thousands of foreign born immigrants, most of whom spoke tongues other than English-all this forms a most interesting chapter in history and sociology. This transfusion has taken place under conditions unusually favorable for peaceful political life and prosperous industry; and if there is aught worth while in the narrative of the quiet progress of this western commonwealth the story must needs be not only picturesque and inspiring, but instructive. 
Copyright of Annals of Iowa is the property of State of Iowa, by \& through the State Historical Society of Iowa and its content may not be copied or emailed to multiple sites or posted to a listserv without the copyright holder's express written permission. However, users may print, download, or email articles for individual use. 